\title{
FRESHWATER SAPROPEL: BIOLOGICALLY ACTIVE COMPONENTS AND METHODS OF EXTRACTION

\author{
Aneka Klavina $^{1}$, Agris Auce ${ }^{2}$, Ilona Pavlovska ${ }^{3}$, Ivars Vanadzins ${ }^{4}$
}

\begin{abstract}
Previously, sapropel has been commonly used in agriculture, cosmetology and medicine in its raw form and there has been no generally accepted method or standard for realizing sapropel extract. However, for sapropel usage in medicine, balneology and pharmacy, it is essential to develop quality criteria for raw sapropel and its extracts.

This review aims at discussing and summing up different techniques for extracting bioactive compounds from sapropel as well as the possibilities of creating quality criteria. This paper covers existing analytical techniques and methodologies; currently, there are few extraction methods using several extractants for obtaining bioactive components from raw sapropel. Different freshwater sapropel types have been described and characterized. Bioactive components in sapropel have been identified and explained. Humic acids and fulvic acids have been identified as the main substances and their extraction methods have been listed. Solid-liquid, ultrasound assisted and supercritical fluid extraction methods have been pointed out as the most suitable. Additionally, analysis and storage conditions of the extracts have been discussed.

There have been found to be no commonly accepted standard methods for sapropel extraction, or for the analysis and characterization of the sapropel extracts. For pharmacological applications, a common approach for the extraction process of active substances from sapropel and the analysis procedures of the extracts need to be established. This review will help equip other researchers with the latest information on this topic.
\end{abstract}

UDC Classification: 661.1:615.4, DOI: https://doi.org/10.12955/pns.v1.119

Keywords: Freshwater sapropel, Extraction methods, fulvic acid, humic acid, pharmacy

\section{Introduction}

Sapropel is an organic sediment which accumulates in shallow to deep marine basins, lagoons and lakes. The organic matter in the sapropel composition is obtained from phytoplankton which live in the upper layers of water; materials from plants and aquatic animals in higher layers play an important role in the production of sapropel as well. Generally, fine-grained sediments can deposit alongside the organic sapropel matter, often resulting in a transition from pure sapropel to an almost organic-free mud or 'sapropel mud' (Gomes et al., 2013). Sapropel is thus a rich organic matter that has in it the remains of water organisms (phytoplankton, zooplankton, and macrophytes) and whose formation process differentiates it from its peat precursor (Strakhovenko et al., 2014; Leonova et al., 2015).

Sapropel has long been used as a remedy both in veterinary and human medicine. It has a positive effect on the nervous, endocrine and the cardiovascular systems, it improves the condition of the musculoskeletal system, as well as stimulates the metabolic processes in the liver (Klavina et al., 2019). For a long time, there has been an interest in extracting the active components from sapropel and utilizing them in skin care and other health care procedures.

Freshwater sapropel is usually found as sediments in lakes, and in some cases in marshes and bogs as well, while brackish water sapropel forms in marine reservoirs. Both types are formed by biochemical, microbiological and mechanical processes (Strakhovenko et al., 2014). Freshwater sapropel is mostly found in the territory of northern and eastern Europe. Research conducted in Latvia has shown that high-quality organic sapropel is often found in the parts that are farther away from the sea and located above the sea level. The percentage of organic material in the sapropel found in the lakes of the Latgale region varies from $30 \%$ to $52 \%$, which can be considered a typical value for sapropel formed in similar climatic conditions (Vanags, 2015).

Depending on the concentration of microelements present, sapropel can be divided into the following types: silica sapropel, mixed-type sapropel, organic sapropel and carbonated sapropel. The total amount of sapropel reserves in the lakes of Latgale is $274,106 \mathrm{~m}^{3}$, including $57,106 \mathrm{~m}^{3}$ of organic sapropel with low ash content and 40,106 $\mathrm{m}^{3}$ of carbonated sapropel (Stankevica et al., 2014).

While sapropel sediment is considered to be an insufficiently researched potential source of bioactive compounds likely to be useful in pharmaceuticals and cosmetics, in balneology it is already considered as a substance with healing properties (Herrero et al., 2015). Recent studies have shown that the use of

\footnotetext{
${ }^{1}$ Riga Stradin̦š university, Institute of Occupation Safety and Environmental Health, aneka.klavina@rsu.lv

${ }^{2}$ Riga Stradiņš university, Institute of Occupation Safety and Environmental Health, a@aa.lv

${ }^{3}$ Riga Stradiňš university, Institute of Occupation Safety and Environmental Health, ilona.pavlovska@rsu.lv

${ }^{4}$ Riga Stradiņš university, Institute of Occupation Safety and Environmental Health, ivars.vanadzins@rsu.lv
} 
healing mud in balneology, SPA, aesthetic medicine and pharmaceutical formulations has increased due to the interest in natural remedies. Sapropel gathered from lakes is suggested to have a healing effect due to its low level of mineralization and high concentration of total organic matter (Dolmaa et al., 2011). Sapropel also has a high content of humic substances (HSs) which partake in the healing effect (Dolmaa et al., 2011; Orru et al., 2011; De Melo el at., 2016). Research results suggest that biologically active organic compounds such as HSs, lipids, proteins, carbohydrates and minerals such as sulphides may be responsible for the therapeutic properties of sapropel (Pena-Mendez et al., 2005; Druvietis et al., 1998; Dolmaa et al., 2011). Methods for controlling the biologically active components in the sapropel extract as well as the possibilities of their extraction are important for the use of sapropel in medicine, pharmaceutical production and cosmetics.

\section{Bioactive components in sapropel}

The organic parts of sapropel come from freshwater flora and fauna, which over a long period of time have been transformed under anaerobic and waterlogged conditions. All of the organic compounds have demonstrated biological activities (Wollina, 2009; Garcia-Villen et al., 2018; Winkler et al., 2018).

Naturally formed sapropel consists mainly of HSs and non-humic substances (Kovalenko et al., 2016). Non-humic substances in sapropel sediments can be placed in one of the following categories: carbohydrates or sugars, amino acids, lipids and proteins (Odabasi et al., 2007; Orru et al., 2011). The main lipids in sapropel sediments are hydrocarbons (20.0\%), carboxylic acids $(9.0 \%)$, esters $(7.7 \%)$, steroids (7.4\%) and oxygen-containing compounds (18.0\%) (Dolmaa et al., 2011).

However, most of the interest is targeted at the HSs found in sapropel, which show the most promising possible usage in medicine. HSs are formed through a secondary synthesis of the microbiological decomposition of plants and animal waste; they are not found in the tissues of living organisms (Dolmaa et al., 2011). HS have relatively high molecular weight, they are macromolecules with high redox-activity and show good antioxidant properties (Aeschbacher et al., 2012).

Fractions of HSs are similar but not identical, depending on solubility in alkali and acid (Belzile, Joly, $\& \mathrm{Li}, 1997)$. As specified by these differences, HSs are divided into four fractions: humic acid (HA) that is soluble in water at $\mathrm{pH}>2$ but coagulates by acidification (below $\mathrm{pH}$ 2) (1), hymatomelanic acid (HMA) soluble in spirits such as ethanol (2), fulvic acid (FA) soluble in water at all pH conditions (3), and humin not soluble in water at any pH values (4) (Belzile et al., 1997; Orru et al., 2011). There are different properties like molecular weight, elemental composition and degree of polymerization and distribution of functional chemical groups that also need to be considered when extracting HS from sapropel sediments. Research shows that most of the extraction methods for sapropel sediments have been developed for the extraction of HAs and fulvic acids.

\section{Humic acid}

HA is a major part of the sapropel's organic matter (Dolmaa et al., 2011). The molecular structure of $\mathrm{HA}$ is an aromatic non-organized polymer containing phenolic, carboxylic, as well as hydroxyl, methoxyl, aldehyde and keton groups. Nitrogen and sulphur atoms are also often found (Alexandrova et al., 2013; Spaccini et al., 2019). The average molecular weight is 6500 . The main structural skeleton is made up of poly-functional groups attached to a condensed aromatic ring, with polypeptides and polysaccharides bound to it (Alexandrova et al., 2013). HAs are found to range from a yellowish to a dark brown colour and to lend the HS its colour. They are found to be soluble in water at higher $\mathrm{pH}$ values but insoluble under acidic conditions (Caseldine et al., 2000).

The HA molecule reacts with the cell walls of an organism as well as with the receptors in the dermis due to the aromatic nucleus and functional groups, additionally penetrating through tissues and producing a therapeutic effect (Alexandrova et al., 2013; Canellas et al., 2015; Jacob et al., 2019). HA facilitates the regeneration of nervous tissues, stimulates the macrophage defence reactions and tissue reparation, as well produces an anti-inflammatory effect in the case of tissue burns and cornea diseases (Dolmaa et al., 2011; Rensburg, 2015).

HA does not show toxic effects in a wide range of dosages tested in animal trials after oral administration or application onto the skin (De Melo et al., 2016; Trofimova et al., 2017; Almeida et al., 2019). However, the usage of HA in medicine is a tough task for pharmacists, because HAs have 
heterogenic structures, polydispersity and properties that depend on source material (Trofimova et al., 2017).

Fulvic acid

Another important HS fraction is FA; FAs are a combination of weak aliphatic and aromatic acids, which are soluble in any $\mathrm{pH}$ value (Belzile et al., 1997). The size of the FA molecules is smaller than those of HA. Nonetheless, the absorption capacity is $2-20$ times higher than that of HA due to the functional groups - carboxyl, phenolic and carbonyl groups associated with macromolecules and with its aliphatic or organic carbons ( $\mathrm{Li}$ et al., 2018). The Oxygen content in FA is higher than that in HA and the average molecular weight is 1200 . Because of its comparatively smaller molecule size, FA can enter deeper levels of tissue. Likewise, there is evidence that FA can carry trace elements from surfaces into tissues (Pena-Mendez et al., 2005). On account of these characteristics, FAs have been used to increase plants' productive capacities as the FAs transport trace minerals directly to the metabolic sites in plant cells.

Furthermore, FA shows a partially agonistic effect on the smooth muscle fibre's $\alpha 2$ adrenoceptor and D2 dopamine receptors, while at the same time influencing spontaneous contractile activity of smooth muscles ( Beer et al., 2002; Beer et al., 2000;).

\section{Extraction of bioactive components from sapropel}

There are many different techniques that can be used to gain extracts from sapropel, such as solidliquid extraction (SLE) with various solvents, microwave-assisted extraction (MAE), ultrasoundassisted extraction (UAE), supercritical fluid extraction (SFE), accelerated solvent extraction (ASE) or hydrostatic pressure extraction (HHPE) (Ryzhova et al., 2013; Xu et al., 2017; Belwal et al., 2018). All these techniques have a proven effectiveness in extraction from natural matrices, follow principles of maximizing the yield of extraction, can be adaptable for industry, have procedures to avoid impurities and toxic compounds, and ensure pharmaceutical grade quality of the final product (Mirza, et al., 2011a; Mirza, et al., 2011b; Belwal et al., 2018).

The first step of extraction is to secrete active components from cells. In the event that they do not distribute, a disruption of cell membranes by mechanical or non-mechanical processes must be applied (Roux et al., 2017). This can be a physical process - drying, osmotic shock, freezing or cooking, a chemical process - applying acid, base, surfactants, or the goal can be reached through biological or enzymatic means. The choice of the fitting cell disruption method depends on the cellular matrix and cell-wall characteristics (Saini et al., 2018). In the case of the sapropel extract, cell disruption usually is done by drying samples before the extraction process and then applying alkaline solution.

Lake sediments consist of crystalline, skeleton-like sand and clay, and residues of water organisms such as flora and fauna. Together these make a colloidal mud solution which has a complex cellular matrix. Bioactive substances are enclosed inside the cells and are often poorly extracted, thus choosing the right cell disruption method is crucial (Ryzhova et al., 2013a).

Another aspect of green and efficient extraction of biologically active compounds from sapropel is by choosing the right solvent; extensively used extractants are water or alkaline solution (Booij et al., 1992; Dolmaa et al., 2011; Ryzhova et al., 2013a).

Extraction and analysis of bioactive compounds from raw sapropel follows various steps summarized in Fig. 1.

\section{Methods for extracting humic substances from sapropel}

A literature review shows that the classical method of extracting HA and FA from sediments utilizes a strong basic substance to extract the alkaline-soluble materials, followed by a removal of the nonsoluble fraction and ends with partitions of HA and FA. There is one common extraction procedure extraction with a sodium hydroxide solution (Ryzhova et al., 2013). Ultrasound-assisted extraction changes HA activity and structure but is commonly used to gain a higher extraction efficacy. Concentration of HS in an extract can vary due to the differences in the chemical structure of the HS or the physical availability of the organic material associated with the minerals in the sapropel (De Paoliset et al., 1997; Javanshah et al., 2016; Klucakova et al., 2017). 


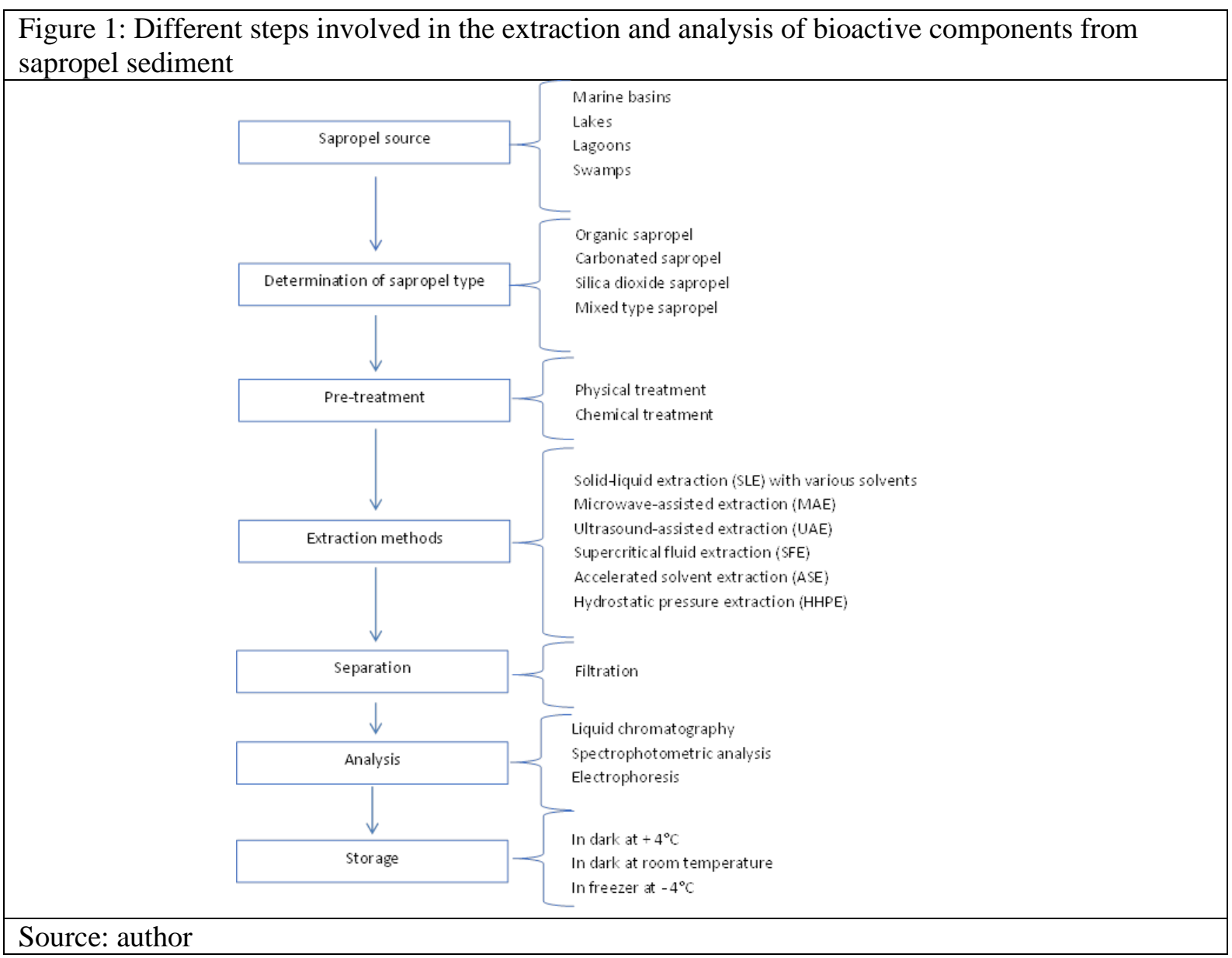

\section{Extraction with sodium hydroxide}

Sodium hydroxide was found to be the extractant most widely used in researchers studies. The concentration of sodium hydroxide used in the extraction process in most studies was ranged from 0.1 to $0.3 \mathrm{~N}$ solution. The extraction time varied from 20 to $48 \mathrm{hrs}$. The mixture (dried sapropel and alkaline solution) was stirred for 5 to $20 \mathrm{hrs,} \mathrm{after} \mathrm{which} \mathrm{the} \mathrm{alkaline} \mathrm{suspension} \mathrm{was} \mathrm{decanted} \mathrm{or} \mathrm{left}$ to stand at a room temperature (Lamar et al., 2014; Javanshah et al., 2016; Belwal et al., 2018). Following this the suspension was centrifuged, usually for $30 \mathrm{~min}$ at $3000-5000 \mathrm{rpm}$ (Klucakova et al., 2017). The sapropel containing a higher clay fraction solution was filtrated through a nuclear filter to ensure that the extract was free of clay particles. Some researchers used $0.45 \mu \mathrm{m}$ filters. The alkaline extract contained HS; the insoluble part was washed with distilled water to separate all the soluble HSs and then discarded (Caseldine et al., 2000; Dolmaa et al., 2011; Orru et al., 2011; Alexandrova et al., 2013). Alkaline supernatant containing HA and FA was acidified (pH 2) with a 6 $\mathrm{N} \mathrm{HCl}$ solution to flocculate the HA. The typical time for separating HA from the solution varied from 1 to 6 hrs depending on the sapropel type (Klavina et al., 2019). Residues were filtered and washed with distilled water and dried (Orru et al., 2011; Alexandrova et al., 2013; Lamar et al., 2014) and the solution was preserved for future preparation and purification of FA (Caseldine et al., 2000). The colour of the extracted HS indicated the HA and FA concentration in the sapropel extract (Caseldine et al., 2000; Alexandrova et al., 2013).

It was thus found that extraction with $\mathrm{NaOH}$ can produce high yields of organic matter, however extraction must be repeated several times to reach maximum recovery (Javanshah \& Saidi, 2016). Despite the good results from $\mathrm{NaOH}$ extraction, there are some disadvantages. In the $\mathrm{NaOH}$ solution at boiling temperatures high molecular components break down to a lower molecular weight such as FA, amino acids and polysaccharide groups and other volatile small molecular width components until no HA is present in the extract (Caseldine et al., 2000). However, following standard procedures eliminates the unwelcome breakdown of $\mathrm{HA}$, and if the disadvantages are overcome, $\mathrm{NaOH}$ extraction 
shows good selectiveness, is easy to use and has economic advantages (Caseldine et al., 2000; Alexandrova et al., 2013).

Some researchers used another extractant for HA and FA extraction process - sodium pyrophosphate. Sediments were dried and treated with $0.1 \mathrm{M} \mathrm{Na}_{4} \mathrm{P}_{2} \mathrm{O}_{7}$ solution ( $\mathrm{pH}$ 10.5), shaken at room temperature for $24 \mathrm{hrs}$, after which the soluble part was separated using a centrifuge (Belzile et al., 1997; Lamar et al., 2014), followed by acidification. Sodium pyrophosphate was found to be a good choice for sediments with high calcium content or carbonated sapropel as sodium pyrophosphate also dissolves metal-organic complexes that reduce organic matter availability, however in such a case the end extract could be contaminated with heavy metals (Javanshah et al., 2016).

\section{Separation of the Fulvic Acid}

In both extraction procedures, FA was separated from other acid-soluble compounds after HA precipitation. For separation DAX-8 or a similar resin such as XAD-7 was used; in some studies this process was called 'the hydrophobic strong acid fraction of soluble organic matter' (Chunxia et al., 1996; Lamar et al., 2014).

A glass column $(40 \times 250 \mathrm{~mm})$ was prepared with a non-ionic macro-porous resin and the FA extract was passed through the column under low pressure. Based on selective absorption, hydrophilic acidsoluble compounds did not bind to the resin and could be removed. After removing salts with $0.01 \mathrm{M}$ $\mathrm{HCl}$, the FA fraction was recovered by elution with a $0.1 \mathrm{M} \mathrm{NaOH}$ solution. The gathered fraction was dried (Khanna et al., 2008; Orru et al., 2011; Lamar et al., 2014).

However, some research shows that FA separation is not needed and that sapropel extract after HA filtration can be used in the preparation of dosage forms (Beer et al., 2003; Klavina et al., 2019).

\section{Technical extraction methods for sapropel sediments}

\section{Solid-liquid extraction}

Generally SLE consists of a straight extraction of fresh, dried or freeze-dried material with different solvents, solvent mixtures or aqueous phases with various $\mathrm{pH}$ levels. It requires subsequent column chromatography or solid-phase extraction to remove unwanted compounds. SLE is uncomplicated and not difficult to operate, however, there are some disadvantages with this method including a long extraction time, low efficiency and hazardous solvents, but with the latest techniques these problems could be overcome (Dujmov et al., 1992; Murthy et al., 1996; De Paolis et al., 1997; Hautala et al., 1998; MacCarthy, 2001; Peuravuori et al., 2002; Morgan et al., 2005; Ryzhova et al., 2013; Klucakova et al., 2017; Xu et al., 2017).

\section{Ultrasound-assisted extraction}

UAE is an applicable and economic technique; it does not require expensive instruments and is easy to use. Sonication is the creation of sound waves that make cavitation bubbles around organic material, disrupting the plant cells and releasing bioactive components into the solution. The method's efficiency depends on the sonication time, temperature, ultrasound wave frequency, as well as the solvent's polarity and sample's properties (Xu et al., 2017). UAE is an adequate technique for sapropel samples (Ryzhova et al., 2013; Nsengumuremyi et al., 2018) because it can be applied to a wet biomass without extra solvent being used, thereby showing good results for lipid extraction from microalgae (Roux et al., 2017). UAE used for sapropel samples shows that it changes the structure, composition and chemical activity of a HS, making it more active and bioavailable ( Ryzhova et al., 2013; Rumyantsev et al., 2017; Nsengumuremyi et al., 2018). Ultrasound has been endorsed in the pharmaceutical extraction industry for a broad range of plant extracts (Vilkhu et al., 2008). Overall, UAE reduces solvent usage and allows the use of less hazardous solvents, providing environmental, health and safety benefits (Vilkhu et al., 2008; Belwal et al., 2018;).

Supercritical fluid extraction

The latest extraction method is SFE, which can be used as an alternative to all the previous methods and is environmentally friendly. The fluid most often used is the supercritical $\mathrm{CO}_{2}$, however, other supercritical fluids such as ethane, butane, nitrous oxide, ammonia and water can also be used in the extraction processes. $\mathrm{CO}_{2}$ is a non-polar, supercritical fluid and is unable to extract polar chemical substances. Nevertheless, by optimizing key parameters and using modified supercritical fluid combination, the extraction efficiency can be improved (Nguta et al., 2016). In such a case subcritical 
water extraction can be used; it is a promising technology for the bio refinery industry and is applicable to a large scale of samples (Roux et al., 2017). To obtain sapropel extract with the supercritical fluid extraction method, $\mathrm{CO}_{2}$ must be used. Results show that time and temperature are crucial paramateres for gaining a maximum concentration of bioactive substances from the sapropel (Krivonos et al., 2010). SFE consumes less toxic organic solvents and lowers the extraction time, increasing the selectivity of bioactive compounds and avoiding sample oxidation. While SFE is thus a green and efficient technique, it requires a large capital investment ( Xu et al., 2017; Saini et al., 2018). The major advantages and disadvantages of various extraction methods for HAs and FAs are described in Table 1.

Extract analysis and storage

While there are no commonly accepted parameters for the characterisation of the sapropel extract, as per pharmacopoeia guidelines, the minimal quality criteria for plant extracts are: moisture content, foreign matter, microbial count, pesticide and heavy metal residue, density, viscosity (for liquids), total ash value, refractive index and microscopic examination if necessary.

Literature review results show that in recent years, chromatographic, spectroscopic and electrophoretic methods for analysis and characterization of HSs have been used. To gain a better understanding of the HS fraction of the extract, analyses have been performed directly after the extraction process. One of the techniques is based on high-performance liquid chromatography (HPLC) (Beer et al., 2000; 2002; 2003; Almeida et al., 2019) with fluorometric detection, and the second is based on capillary zone electrophoresis (CZE) with UV detection. Both methods can be used to determine the HA fraction after single extraction and do not require additional purification steps (Orru et al., 2011; Javanshah et al., 2016). Some studies used the methods of conductometric and potentio-metric titrations (Klucakova et al., 2005). However the UV-Vis spectrum method is commonly used to determine HA concentration in soil and sediment samples, but it needs extra sample purification before analysis (Caseldine et al., 2000; Morgan et al., 2005; Khanna et al., 2008; Alexandrova et al., 2013). For determination of chemical and compositional structure of HS, FTIR spectroscopy and elemental analysis are used (De Paolis \& Kukkonen, 1997; Belzile et al., 1997; Caseldine et al., 2000; Khanna et al., 2008; Dolmaa et al., 2011; Alexandrova et al., 2013). The elemental composition determines the origin of the material, and the $\mathrm{O}: \mathrm{C}$ ratio is considered to be an indicator of $\mathrm{HS}$ carbohydrates. Further, hydrogen carbon $(\mathrm{H}: \mathrm{C})$ and nitrogen carbon $(\mathrm{N}: \mathrm{C})$ ratios are used to monitor structural changes in sediments and extracts (Belzile et al., 1997; De Paolis et al., 1997; Dolmaa et al., 2011).

Depending on the extracted fraction from sapropel, there are different ways to store it. If the extracted fraction contains lipids and organic solvents were used in the extraction process, the obtained extract stored at $4^{\circ} \mathrm{C}$ was found to remain stable for several months (Shamia et al., 2017; Rasaee et al., 2018). Suarez Munoz (Suarez et al., 2015) also reported that dried HA fraction stored at $4^{\circ} \mathrm{C}$ and maintained stable. FA fraction has commonly been frozen or freeze-dried and stored at $-4{ }^{\circ} \mathrm{C}$ for future usage (Beer et al., 2003; Khanna et al., 2008; Dolmaa et al., 2011; Suarez et al., 2015; Meullemiestre et al., 2017).

Studies suggest that all of the extracts are chemically stable and retain their biological activity for months in aqueous solutions and can be used for pharmaceuticals (Beer et al., 2002, 2003; Mirza et al., 2011a; Mirza et al., 2011b).

\section{Conclusion}

The key purpose of extraction of active components from sapropel is to use them in cosmetic, medical or pharmacological products. The use of sapropel extract in medicine and pharmacology is complicated by the fact that it does not have stoichiometric composition, varies in structural composition, and is characterized by heterogeneity and polydispersity. In existing literature there is no commonly used standard for obtaining sapropel extract or analysing its value for pharmaceutical purposes.

Pharmacopoeia standards suggest that factors ensuring the quality of plant material should be defined.

The characteristics of the sapropel sediment - its origin, type, microbiology, moisture content, total organic substances and extraction parameters (e.g. solvent, pressure, temperature, and extraction cycles) are the most vital elements influencing the efficiency of extraction. Additionally, sample pre- 
treatment with physical and chemical approaches such as drying and freezing can affect the outcome of extraction as well the appropriate storage needed for the extracted material.

\begin{tabular}{|c|c|c|c|c|c|}
\hline $\begin{array}{c}\text { Sapropel } \\
\text { type }\end{array}$ & $\begin{array}{c}\text { Extraction } \\
\text { method }\end{array}$ & $\begin{array}{c}\text { Material } \\
\text { pre- } \\
\text { treatment }\end{array}$ & Solutions & $\begin{array}{c}\text { Advantages (A) } \\
\text { Disadvantages (D) }\end{array}$ & References \\
\hline 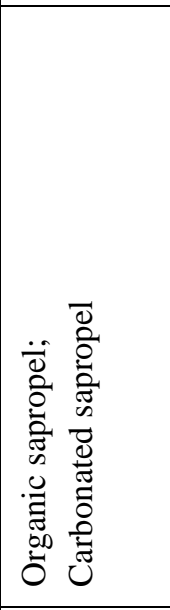 & 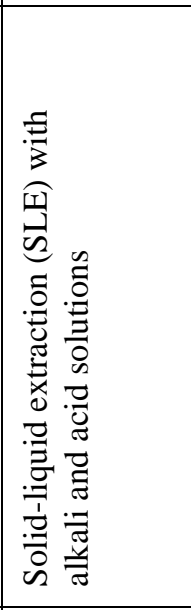 &  &  & 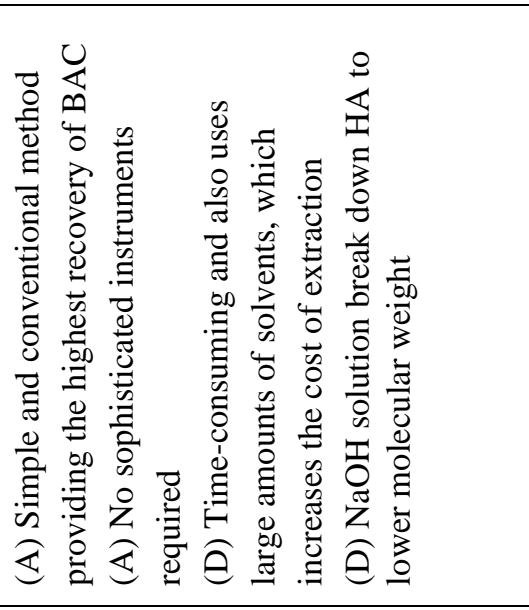 & $\begin{array}{l}\text { ( Dujmov et al., } \\
\text { 1992; Murthy et } \\
\text { al., 1996; De } \\
\text { Paolis et al., } \\
\text { 1997; Hautala et } \\
\text { al., 1998; } \\
\text { MacCarthy, } \\
\text { 2001; } \\
\text { Peuravuori et } \\
\text { al., 2002; } \\
\text { Morgan et al., } \\
\text { 2005; Ryzhova } \\
\text { et al., 2013; } \\
\text { Klucakova et } \\
\text { al., 2017) } \\
\end{array}$ \\
\hline 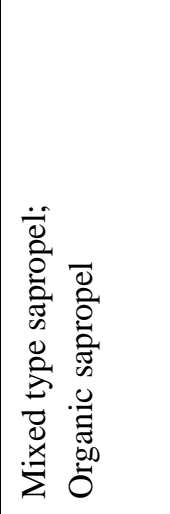 &  & $\stackrel{\mathscr{Z}}{\mathscr{O}}$ & 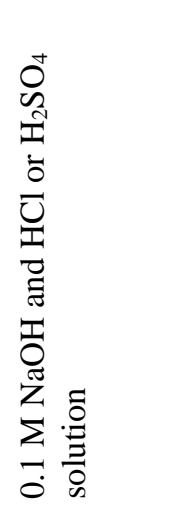 &  & $\begin{array}{l}\text { ( MacCarthy, } \\
\text { 2001; Beer et } \\
\text { al., 2003; } \\
\text { Klavins \& } \\
\text { Purmalis, 2010; } \\
\text { Rensburg, 2015; } \\
\text { McDonnell \& } \\
\text { Tiwari, 2017; } \\
\text { Zanin et al., } \\
\text { 2018) }\end{array}$ \\
\hline 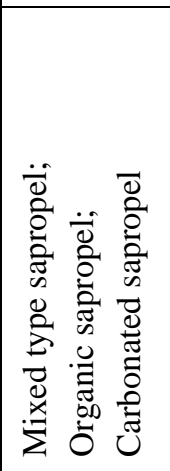 & 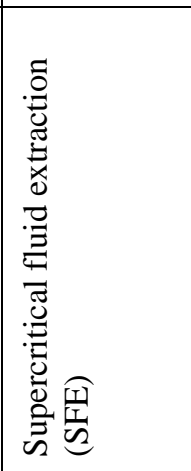 & $\stackrel{\mathscr{\Xi}}{\mathscr{\Xi}}$ & Oَ & 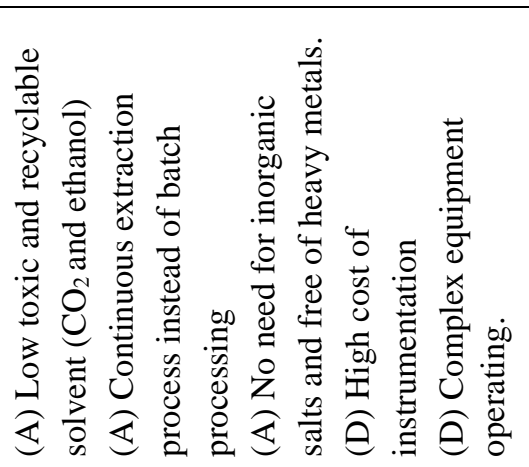 & $\begin{array}{l}\text { ( Plaksin, 2010; } \\
\text { Krivonos et al., } \\
\text { 2018; Xu et al., } \\
\text { 2017) }\end{array}$ \\
\hline
\end{tabular}

Source: author

Moreover, a large number of studies have been conducted to evaluate the HS extraction from sapropel, but no generally accepted recommendations can be deduced because of the diversity in the sapropel sediments. The most suitable method for obtaining sapropel extract is $\mathrm{NaOH}$ water solution extraction with different $\mathrm{pH}$ values and sonication in various temperatures. As for sapropel extract analysis, there are no guidelines; however, the most commonly used method for the determination of HAs and FAs are HPLC. For other suggested parameters in pharmacopoeia there are no data available in literature, and sufficient experimental data is lacking in the existing methods.

Sapropel extract has good commercial potential for use in cosmetics and pharmaceuticals and its increasing economic significance can lead to the finding of more sophisticated extraction and standardisation methods in the future. 


\section{Acknowledgement}

This research was financed under 'Analysis of characteristics of medical sapropel and its usage for medical purposes and elaboration of industrial extraction methods', project no. 1.1.1.1/16/A/165.

\section{References}

Aeschbacher, M., Graf, C., Schwarzenbach, R. P., Sander, M. (2012). Antioxidant properties of humic substances. Environmental Science \& Technology, 46(9), 4916-4925. https://doi.org/10.1021/es300039h

Alexandrova, G. P., Dolmaab, G., Tserenpil, S., Grishenko, L. A., Sukhov, B. G., Regdel, D., Trofimov, B. A. (2013). A new humic acid preparation with addition of silver nanoparticles. Functions of Natural Organic Matter in Changing Environment (Vol. 9789400756, pp. 783-788). https://doi.org/10.1007/978-94-007-5634-2_142

Almeida, A. R., Jesus, F., Henriques, J. F., Andrade, T. S., Barreto, A., Koba, O., Giang, P.T., Soares, A.M.V.M., Oliviera M., Domingues, I. (2019). The role of humic acids on gemfibrozil toxicity to zebrafish embryos. Chemosphere, 220, 556564. https://doi.org/10.1016/J.CHEMOSPHERE.2018.12.133

Beer, A. M., Junginger, H. E., Lukanov, J., Sagorchev, P. (2003). Evaluation of the permeation of peat substances through human skin in vitro. International Journal of Pharmaceutics, 253(1-2), 169-175. https://doi.org/10.1016/S03785173(02)00706-8

Beer, A. M., Lukanov, J., Sagorchev, P. (2000). The influence of fulvic and ulmic acids from peat, on the spontaneous contractile activity of smooth muscles. Phytomedicine, 7(5), 407-415. https://doi.org/10.1016/S0944-7113(00)80062-8 Beer, A. M., Sagorchev, P., Lukanov, J. (2002). Isolation of biologically active fractions from the water soluble components of fulvic and ulmic acids from peat. Phytomedicine, 9(7), 659-666. https://doi.org/10.1078/094471102321616490

Belwal, T., Ezzat, S. M., Rastrelli, L., Bhatt, I. D., Daglia, M., Baldi, A., ... Atanasov, A. G. (2018). A critical analysis of extraction techniques used for botanicals: Trends, priorities, industrial uses and optimization strategies. TrAC - Trends in Analytical Chemistry, 100(2018), 82-102. https://doi.org/10.1016/j.trac.2017.12.018

Belzile, N., Joly, H. A., Li, H. (1997). Characterization of humic substances extracted from Canadian lake sediments. Canadian Journal of Chemistry. 75(1), 14-27. https://doi.org/10.1139/v97-003

Booij, K., Achterberg, E. P., Sundby, B. (1992). Release rates of chlorinated hydrocarbons from contaminated sediments. Netherlands Journal of Sea Research, 29(4), 297-310. https://doi.org/10.1016/0077-7579(92)90070-U

Canellas, L. P., Olivares, F. L., Aguiar, N. O., Jones, D. L., Nebbioso, A., Mazzei, P., Piccolo, A. (2015). Humic and fulvic acids as biostimulants in horticulture. Scientia Horticulturae, 196, 15-27. https://doi.org/10.1016/j.scienta.2015.09.013 Caseldine, C. J., Baker, A., Charman, D. J., Hendon, D. (2000). A comparative study of optical properties of NaOH peat extracts: Implications for humi®cation studies. The Holocene, 10(5), 649-658. https://doi.org/10.1191/095968300672976760 Chunxia, W., Zijian, W., Chunlin, Y., Wenhua, W., An, P. (1996). The evidence for the incorporation of fulvic acid into the bone and cartilage of rats. Science of the Total Environment, 191(3), 197-202. https://doi.org/10.1016/S00489697(96)05260-6

De Melo, B. A. G., Motta, F. L., Santana, M. H. A. (2016). Humic acids: Structural properties and multiple functionalities for novel technological developments. 62, 967-974 Materials Science and Engineering $C$.

https://doi.org/10.1016/j.msec.2015.12.001

De Paolis, F., Kukkonen, J. (1997). Binding of organic pollutants to humic and fulvic acids: Influence of $\mathrm{pH}$ and the structure of humic material. Chemosphere, 34(8), 1693-1704. https://doi.org/10.1016/S0045-6535(97)00026-X

Dolmaa, G., Tserenpil, S., Ugtakhbayar, O., Shevchenko, S., Kliba, L., Voronkov, M. (2011). Characterization and Organic Compounds in Peloids from Mongolia. Proceedings of the Mongolian Academy of Sciences, 49(4) 3-21.

https://doi.org/10.5564/pmas.v0i4.42

Druvietis, I., Springe, G., Urtane, L., Klavins, M. (1998). Evaluation of plankton communities in small highly humic bog lakes in Latvia. Environment International, 24(5-6), 595-602. https://doi.org/10.1016/S0160-4120(98)00038-5

Dujmov, J., Sucevic, P., Antolic, B. (1992). UV-fluorescence spectrophotometric assessment and characterization of dissolved fluorescent matter in coastal water of the central adriatic. Netherlands Journal of Sea Research, 29(4), 291-296. https://doi.org/10.1016/0077-7579(92)90069-Q

Garcia-Villen, F., Sanchez-Espejo, R., Carazo, E., Borrego-Sanchez, A., Aguzzi, C., Cerezo, P., Viseras, C. (2018). Characterisation of Andalusian peats for skin health care formulations. Applied Clay Science, 160, 201-205. https://doi.org/10.1016/j.clay.2017.12.017

Gomes, C., Carretero, M. I., Pozo, M., Maraver, F., Cantista, P., Armijo, F., ... Delgado, R. (2013). Peloids and pelotherapy: Historical evolution, classification and glossary. Applied Clay Science, 75-76, 28-38.

https://doi.org/10.1016/j.clay.2013.02.008

Hautala, K., Peuravuori, J., Pihlaja, K. (1998). Organic compounds formed by chemical degradation of Lake Aquatic humic matter. Environment International 24, 527-536. https://doi.org/10.1016/S0160-4120(98)00047-6

Herrero, M., Sanchez-Camargo, A. del P., Cifuentes, A., Ibanez, E. (2015). Plants, seaweeds, microalgae and food byproducts as natural sources of functional ingredients obtained using pressurized liquid extraction and supercritical fluid extraction. TrAC - Trends in Analytical Chemistry, 71, 26-38. https://doi.org/10.1016/j.trac.2015.01.018

Jacob, K. K., Prashob Peter, K. J., Chandramohanakumar, N. (2019). Humic substances as a potent biomaterials for therapeutic and drug delivery system-a review. International Journal of Applied Pharmaceutics, 11(3), 1-4. https://doi.org/10.22159/ijap.2019v11i3.31421

Javanshah, A., Saidi, A. (2016). Determination of Humic Acid by Spectrophotometric Analysis in the Soils. International 
Journal of Advanced Biotechnology and Research (IJBR), 7, 19-23. Retrieved from http://www.bipublication.com Khanna, R., Witt, M., Khalid Anwer, M., Agarwal, S. P., Koch, B. P. (2008). Spectroscopic characterization of fulvic acids extracted from the rock exudate Shilajit. Organic Geochemistry, 39(12), 1719-1724. https://doi.org/10.1016/j.orggeochem.2008.08.009

Klavina, A., Auce, A., Vanadzins, I., Silova, A., Dobkevica, L. (2019). Extraction of boilogically active components from freshwater sapropel. Environment. Technology. Resources. Proceedings of the International Scientific and Practical Conference, 3, 114. https://doi.org/10.17770/etr2019vol3.4135

Klavins, M., Purmalis, O. (2010). Humic substances as surfactants. Environmental Chemistry Letters, 8(4), 349-354. https://doi.org/10.1007/s10311-009-0232-z

Klucakova, M., Pekar, M. (2005). Solubility and dissociation of lignitic humic acids in water suspension. Colloids and Surfaces A: Physicochemical and Engineering Aspects, 252(2), 157-163. https://doi.org/10.1016/j.colsurfa.2004.10.019

Klucakova, M., Veznikova, K. (2017). Micro-organization of humic acids in aqueous solutions. Journal of Molecular Structure, 1144, 33-40. https://doi.org/10.1016/j.molstruc.2017.05.012

Kovalenko, G. A., Perminova, L. V., Rudina, N. A., Maksimova, Y., Maksimov, A. Y. (2016). Sapropel-based supports as novel macroporous carbon-mineral adsorbents for enzymatic active substances. Resource-Efficient Technologies, 2(4), 159167. https://doi.org/10.1016/j.reffit.2016.09.001

Krivonos, I. O., Plaksin, G. V. (2010). Extraction of Biologically Active Substances from Sapropels with Liquid and Supercritical Carbon Dioxide. Russian Journal of Physical Chemistry, 4(8), 1171-1177.

Krivonos, O. I., Belskaya, O. B. (2018). Extraction of sapropel d 0- and supercritical carbon dioxide. III REGIONAL SCIENTIFIC AND TECHNICAL CONFERENCE "SCIENTISTS OMSKA TO THE REGION", 1, 81-83.

Lamar, R. T., Olk, D. C., Mayhew, L., Bloom, P. R. (2014). A new standardized method for quantification of humic and fulvic acids in humic ores and commercial products. Journal of AOAC INTERNATIONAL, 97(3), 721-730. https://doi.org/10.5740/jaoacint.13-393

Leonova, G. A., Bobrov, V. A., Krivonogov, S. K., Bogush, A. A., Bychinskii, V. A., Mal'tsev, A. E., \& Anoshin, G. N. (2015). Biogeochemical specifics of sapropel formation in Cisbaikalian undrained lakes (exemplified by Lake Ochki). Russian Geology and Geophysics, 56(5), 745-761. https://doi.org/10.1016/j.rgg.2015.04.006

Li, H., Wang, J., Zhao, B., Gao, M., Shi, W., Zhou, H., ... He, J. (2018). The role of major functional groups: Multi-evidence from the binding experiments of heavy metals on natural fulvic acids extracted from lake sediments. Ecotoxicology and Environmental Safety, 162, 514-520. https://doi.org/10.1016/J.ECOENV.2018.07.038

MacCarthy, P. (2001). The principles of humic substances. Soil Science, 166(11), 738-751. https://doi.org/10.1097/00010694-200111000-00003

McDonnell, C., Tiwari, B. K. (2017). Ultrasound: A Clean, Green Extraction Technology for Bioactives and Contaminants. Comprehensive Analytical Chemistry, 76, 111-129. https://doi.org/10.1016/bs.coac.2017.03.005

Meullemiestre, A., Breil, C., Abert-Vian, M., Chemat, F. (2017). Manothermosonication as a useful tool for lipid extraction from oleaginous microorganisms. Ultrasonics Sonochemistry, 37, 216-221. https://doi.org/10.1016/j.ultsonch.2017.01.014

Mirza, M. A., Agarwal, S. P., Rahman, M. A., Rauf, A., Ahmad, N., Alam, A., Iqbal, Z. (2011). Role of humic acid on oral drug delivery of an antiepileptic drug. Drug Development and Industrial Pharmacy, 37(3), 310-319. https://doi.org/10.3109/03639045.2010.512011

Mirza, M. A., Ahmad, N., Agarwal, S. P., Mahmood, D., Anwer, M. K., \& Iqbal, Z. (2011). Comparative evaluation of humic substances in oral drug delivery. Results in Pharma Sciences, 1(1), 16-26. https://doi.org/10.1016/j.rinphs.2011.06.001

Morgan, T. J., Herod, A. A., Brain, S. A., Chambers, F. M., Kandiyoti, R. (2005). Examination of soil contaminated by coalliquids by size exclusion chromatography in 1-methyl-2-pyrrolidinone solution to evaluate interference from humic and fulvic acids and extracts from peat. Journal of Chromatography A, 1095(1-2), 81-88.

https://doi.org/10.1016/j.chroma.2005.07.116

Murthy, N. B. K., Moza, P. N., Hustert, K., Raghu, K., Kettrup, A. (1996). Photolysis of thiabendazole in aqueous solution and in the presence of fulvic and humic acids. Chemosphere, 33(10), 1915-1920. https://doi.org/10.1016/00456535(96)00313-X

Nguta, J. M., Appiah-Opong, R., Nyarko, A. K., Yeboah-Manu, D., Addo, P. G. A., Otchere, I., \& Kissi-Twum, A. (2016). Antimycobacterial and cytotoxic activity of selected medicinal plant extracts. Journal of Ethnopharmacology, 182, 10-15. https://doi.org/10.1016/j.jep.2016.02.010

Nsengumuremyi, Daniel, Barakova, N.V., Romanov, V.A., Mityukov, A.S., Guzeva, A. V. (2018). The effect of saprope extracts on microflora and physicochemical parameters of Dried Distillers ' Grain. Agronomy Research, 16(May), 14571465. https://doi.org/10.15159/AR.18.096

Odabasi, E., Gul, H., Macit, E., Turan, M., Yildiz, O. (2007). Lipophilic components of different therapeutic mud species. Journal of Alternative and Complementary Medicine (New York, N.Y.), 13(10), 1115-1118. https://doi.org/10.1089/acm.2007.0504

Orru, M., Ubner, M., Orru, H. (2011). Kolme balneoloogilise potentsiaaliga Eesti turbaala turba keemilised omadused. Estonian Journal of Earth Sciences, 60(1), 43-49. https://doi.org/10.3176/earth.2011.1.04

Pena-Mendez, E. M., Havel, J., Patocka, J. (2005). Humic substances - compounds of still unknown structure: applications in agriculture, industry, environment, and biomedicine. Journal of Applied Biomedicine, 3(1), 13-24. https://doi.org/10.32725/jab.2005.002

Peuravuori, J., Koivikko, R., Pihlaja, K. (2002). Characterization, differentiation and classification of aquatic humic matter 
separated with different sorbents: synchronous scanning fluorescence spectroscopy. Water Research, 36(18), 4552-4562. https://doi.org/10.1016/S0043-1354(02)00172-0

Rasaee, I., Ghannadnia, M., Baghshahi, S. (2018). Biosynthesis of silver nanoparticles using leaf extract of Satureja hortensis treated with $\mathrm{NaCl}$ and its antibacterial properties. Microporous and Mesoporous Materials, 264, 240-247. https://doi.org/10.1016/j.micromeso.2018.01.032

Rensburg, C. E. J. van. (2015). The Antiinflammatory Properties of Humic Substances: A Mini Review. Phytotherapy Research, 29(6), 791-795. https://doi.org/10.1002/ptr.5319

Roux, J. M., Lamotte, H., \& Achard, J. L. (2017). An Overview of Microalgae Lipid Extraction in a Biorefinery Framework. Energy Procedia, 112, 680-688. https://doi.org/10.1016/j.egypro.2017.03.1137

Rumyantsev, V. A., Mityukov, A. S., Kryukov, L. N., Yaroshevich, G. S. (2017). Unique properties of humic substances from sapropel. Doklady Earth Sciences, 473(2), 482-484. https://doi.org/10.1134/S1028334X17040201

Ryzhova, G. L., Tyunina, M. A., \& Dychko, K. A. (2013a). Determination of fatty acids in products of the vibromagnetic treatment of sapropel by chromatography-mass spectrometry. Journal of Analytical Chemistry, 68(8), 736-742. https://doi.org/10.1134/S1061934813080108

Ryzhova, G. L., Tyunina, M. A., \& Dychko, K. A. (2013b). Determination of Fatty Acids in Sapropel Products by Chromatography-Mass Spectrometry. Journal of Analytical Chemistry (RUS), 68(8), 808-814. https://doi.org/10.7868/S0044450213080112

Saini, R. K., Keum, Y. S. (2018). Carotenoid extraction methods: A review of recent developments. Food Chemistry, 240, 90-103. https://doi.org/10.1016/j.foodchem.2017.07.099

Shamia, I. S., Halabi, M. N., El-ashgar, N. M. (2017). Humic Acid Determination in some Compost and Fertilizer Samples. Journal of Natural Studies, 25, 42-50.

Spaccini, R., Cozzolino, V., Di Meo, V., Savy, D., Drosos, M., Piccolo, A. (2019). Bioactivity of humic substances and water extracts from compost made by ligno-cellulose wastes from biorefinery. Science of the Total Environment, 646, 792-800. https://doi.org/10.1016/j.scitotenv.2018.07.334

Stankevica, K., Klavins, M. (2014). Sapropel and Its Application Possibilities. Material Science and Applied Chemistry, 29(29), 109. https://doi.org/10.7250/msac.2013.028

Strakhovenko, V. D., Taran, O. P., Ermolaeva, N. I. (2014). Geochemical characteristics of the sapropel sediments of small lakes in the Ob'-Irtysh interfluve. Russian Geology and Geophysics, 55(10), 1160-1169.

https://doi.org/10.1016/j.rgg.2014.09.002

Suarez Munoz, M., Melian Rodriguez, C., Gelen Rudnikas, A., Diaz Rizo, O., Martinez-Santos, M., Ruiz-Romera, E., .. Gonzalez-Hernandez, P. (2015). Physicochemical characterization, elemental speciation and hydrogeochemical modeling of river and peloid sediments used for therapeutic uses. Applied Clay Science, 104, 36-47. https://doi.org/10.1016/j.clay.2014.11.029

Trofimova, E. S., Zykova, M. V, Ligacheva, A. A., Sherstoboev, E. Y., Zhdanov, V. V, Belousov, M. V, Dygai, A. M. (2017). Influence of humic acids extracted from peat by different methods on functional activity of macrophages in Vitro. Bulletin of Experimental Biology and Medicine, 162(6), 741-745. https://doi.org/10.1007/s10517-017-3702-5

Vanags, R. (2015). Investigation of sapropel extraction technical tools. Engineering for Rural Developmen, 14, 151-154. Vilkhu, K., Mawson, R., Simons, L., Bates, D. (2008). Applications and opportunities for ultrasound assisted extraction in the food industry - A review. Innovative Food Science and Emerging Technologies, 9(2), 161-169. https://doi.org/10.1016/j.ifset.2007.04.014

Winkler, J., Ghosh, S. (2018). Therapeutic Potential of Fulvic Acid in Chronic Inflammatory Diseases and Diabetes. Journal of Diabetes Research, 1-7. https://doi.org/10.1155/2018/5391014

Wollina, U. (2009). Peat: A natural source for dermatocosmetics and dermatotherapeutics. Journal of Cutaneous and Aesthetic Surgery, 2(1), 17. https://doi.org/10.4103/0974-2077.53094

Xu, C. C., Wang, B., Pu, Y. Q., Tao, J. S., Zhang, T. (2017). Advances in extraction and analysis of phenolic compounds from plant materials. Chinese Journal of Natural Medicines, 15(10), 721-731. https://doi.org/10.1016/S18755364(17)30103-6

Zanin, L., Tomasi, N., Zamboni, A., Sega, D., Varanini, Z., Pinton, R. (2018). Water-extractable humic substances speed up transcriptional response of maize roots to nitrate. Environmental and Experimental Botany, 147, 167-178. https://doi.org/10.1016/j.envexpbot.2017.12.014 